\title{
Natural infection potential and efficacy of the entomopathogenic fungus Beauveria bassiana against Orosanga japonica (Melichar)
}

\author{
M. Mustafa Akıner ${ }^{1 *}$, Murat Öztürk', İbrahim Güney ${ }^{1}$ and Asu Usta²
}

\begin{abstract}
In this study, potential of the entomopathogenic fungi (EPF) isolates from dead samples of Orosanga japonica (Melichar) (Hemiptera: Ricaniidae) was evaluated. Infected specimens with fungi results confirmed that the samples were Beauveria bassiana after morphological and molecular identification. Amplicons produced two haplotypes $(h=$ 2), which included one polymorphic site after sequence and named isolates 1 and 2. Two haplotypes were rooted with MK229193.1, MG345084.1 B. bassiana Genbank samples. Two-year survey results of the EPF effects revealed the highest mortality and natural infection rates in the field. Natural mortality rates varied between $80.35 \%$ (FIndıkl1August) and 94.8\% (Çayeli-September) in 2018 and between 79.82\% (Alipaşa-August) and 97.75\% (FındıkıSeptember) in 2019. For nymphs, the lowest $\mathrm{LT}_{50}$ value was found at 2.92 days for isolate 1 and 2.56 days for isolate 2, with a concentration of $1 \times 10^{6}$ conidia/ml, using the leaf dipping method. For adults, the lowest $L T_{50}$ value was found at 3.02 days for isolate 1 and 3.15 days for isolate 2, with a concentration of $1 \times 10^{6}$ conidia/ml, using the direct spraying method. Nymph $L T_{50}$ values were found a little bit lower than adults. Direct spraying methods results gave a high $L T_{50}$ value for nymph in contrast to adult. Although the $L T_{50}$ ratios gave high/low degree in different isolates, methods and life stages, non-significant differences were found between each other's $(p>0.05)$. In general, B. bassiana natural infection rates were found high in August and September during the 2 years. Efficacy of the two isolates, which derived from naturally infected O. japonica specimens, increased with concentration. The two isolates can potentially be used for $O$. japonica integrated management, as a fungal biocontrol agent, but their toxicological effects on beneficial insects, such as honeybees, will need to be determined.
\end{abstract}

Keywords: Orosanga japonica, Beauveria bassiana, Efficacy, Natural infection, Biocontrol

\section{Background}

The Eastern Black Sea region in Turkey is characterized by a mild and rainy climate, favoring the survival of numerous insect pest species from tropical areas. This region has limited agricultural areas, and the most important agricultural products are tea, hazelnut, and kiwi. Insecticide usage is limited because of the

\footnotetext{
* Correspondence: akiner.m@gmail.com

${ }^{1}$ Faculty of Arts and Sciences Department of Biology Rize Turkey, Recep

Tayyip Erdoğan University, Rize, Turkey

Full list of author information is available at the end of the article
}

precipitation regime and the "zero chemical" perspective of the General Directorate of Tea Enterprises in Turkey.

Orosanga japonica (Melichar) (Hemiptera: Ricaniidae) is an invasive species in the western Palearctic region and widespread in the Black Sea area countries (Georgia, Ukraine, Russia, Turkey, and Iran) (Demir, 2018 and Mozaffarian, 2018). Rising population levels of O. japonica have become a considerable problem in the Eastern Black Sea region in Turkey, since the species was first detected in 2006 (Demir, 2009). O. japonica is a pest insect in tropical regions and recently, it was reported on 
chestnut in Abhazia, orchards in Iran as well as tea and kiwifruit in Turkey (Mozaffarian, 2018). Adults and nymphs feed on plant sap, and adults lay their eggs on a wide range of crop plants such as grape, kiwi, tea, beans, corn, cabbage, pepper, and eggplant (Gokturk and Aksu, 2014). Synthetic insecticides-based pest control is an important measure, but they also linked to adverse effects such as environmental contamination and insecticide resistance. Additionally, toxic and detrimental effects on non-target organisms are a problem in many areas (Dinesh et al. 2015). Although different types of biological control agents and mechanical control methods against the adult and nymph stages of $O$. japonica have been investigated (Ak et al. 2013 and Gokturk et al. 2018), more advanced studies are needed.

For insect control, the family Clavicapitaceae constitutes a favorable alternative in this regard (Sung et al. 2007), such as entomopathogenic fungi (EPF), which are distributed throughout many diverse ecological habitats (White et al. 2003). Beauveria bassiana is a well-known EPF species and has a worldwide distribution (Ownley et al. 2008). It belongs to the order Hypocrales (Ascomycota) and infects numerous insect species (Zimmermann, 2007). Several studies have investigated its effectiveness as a biological control agent in agricultural and forestry areas (Inanli et al. 2012 and Guven et al. 2015). B. bassiana can infect more than 70 insect pests, with a potential to control these species (Roy et al. 2006 and Van Lenteren, 2012).

The present study aimed to identify the EPF species that caused high rates of $O$. japonica mortality in the field, to determine natural infection rates under field conditions, and to confirm their efficacy against $O$. japonica under laboratory conditions.

\section{Material and methods}

\section{Isolation of entomopathogenic fungi from naturally} infected samples

Infected O. japonica specimens were collected from the field in 2018 around two locations in Rize city by hand picking. The specimens were placed in falcon tubes and transferred to the laboratory. Specimens collected on kiwifruit in Rize City Center and Findıklı, whole collection points were fruit garden and situated around tea gardens area. Dead O. japonica specimens, infected with fungi, were transferred on potato dextrose agar (PDA) medium and incubated for $15-17$ days at $25 \pm 2{ }^{\circ} \mathrm{C}$ in the dark and their spores were collected (Sevim et al. 2010) and transferred to falcon tubes containing $50 \mathrm{ml}$ of Tween 80 solution $(0.1 \% \mathrm{v} / \mathrm{v})$. The conidia concentrations of the stock solution were determined via direct counting on a Thoma slide under a light microscope. Test conidia concentrations contained $1 \times 10^{4}, 1 \times 10^{5}, 1 \times 10^{6}$ conidia/ $\mathrm{ml}$ for the bioassay. Each fungal set received a code (Rize
City Center islolate 1, Findiklı isolate 2), and the collection area was noted (location, elevation, host plant, date). Isolates stored under sub-culture in PDA and subcultured every months according to the Oliveira et al. (2011) in the RTEU Vector Ecology and Control Laboratory in Rize Turkey.

\section{Determination of fungal isolates}

EPF were identified morphologically and molecularly. Morphological species distinction was made according to Humber (1997). Morphologically identified species were confirmed molecularly for exact determination.

\section{DNA isolation, PCR, and analysis of the sequence data}

The DNA isolation was performed, using the Gene JET genomic DNA Extraction Kit (Thermo Scientific ${ }^{\circ}$ ), according to the manufacturer's instructions. Isolated DNA amounts were measured Qbit and diluted for final PCR volume $(50 \mu \mathrm{l})$. The ITS4-5 regions were amplified according to White et al. (1990). Each PCR reaction was performed, using $\mathrm{T} 100{ }^{\mathrm{mx}}$ Thermal Cycler-Bio-Rad ${ }^{\circ}$; the PCR mix contained 100 ng of genomic DNA, 1 x buffer, $2.5 \mathrm{mM} \mathrm{MgCl} 2,250 \mathrm{mM}$ each dNTP, $100 \mathrm{nM}$ each primer (ITS5 (5'-GGAAGTAAAAGTCGTAACAAGG-3') and ITS4 (5'-TCCTCCGCTTATTGATATCG-3')) and 1 unit of Biolabs ${ }^{\circ}$ Taq polymerase. Amplification conditions were as follows: $3 \mathrm{~min}$ at $95{ }^{\circ} \mathrm{C}$ for initial denaturation, 35 cycles of $60 \mathrm{~s}$ at $95^{\circ} \mathrm{C}$ for denaturation, $30 \mathrm{~s}$ at an annealing temperature of $53{ }^{\circ} \mathrm{C}, 90 \mathrm{~s}$ at $72{ }^{\circ} \mathrm{C}$ for extension and $72{ }^{\circ} \mathrm{C}$ for $5 \mathrm{~min}$ for final extension. Amplicons were visualized using $1.5 \%$ agarose gel and sequenced at Macrogen Inc. (Amsterdam). The sequences were edited using the BIOEDIT program, version 7.0.5.2 (Hall, 1999) and aligned in CLUSTAL W (Thompson et al. 1994). The numbers of haplotypes (h) and polymorphic sites as well as nucleotide diversity $(\pi)$ were calculated using DNAsp version 5.0 (Rozas et al. 2017). The haplotypes identified in the present study were also compared to those available in GenBank samples. The neighbor-joining tree was generated by 1000 bootstrap replications according to the Mega 7 software (Kumar et al. 2016).

\section{Test organisms}

Nymphs and adults of O. japonica were collected by an electric aspirator from four different localities at Rize in 2019 for the laboratory experiment. Specimens collected on kiwifruit in Rize City Center (Lon 41.0364 Lat 40.4934) and Findıklı (Lon 41.2855 Lat 41.1715), on blackberry in Alipasa (Lon 41.0278 Lat 40.4494) and Cayeli (Lon 41.0963 Lat 40.7336). Whole collection points are fruit garden and situated around tea gardens area. Collection was performed with electric aspirator during $5 \mathrm{~min}$ and collected samples were placed in the 
net cages. Collected samples were transferred to the laboratory and placed in previously sterilized rearing cages. Samples were kept at $25 \pm 2{ }^{\circ} \mathrm{C}, 65 \pm 10 \% \mathrm{RH}$ and a photoperiod regime of 12:12 $\mathrm{h}$ light/dark in the insectarium. Fresh plant branches (blackberry) were placed into the cages for feeding. Fresh plant branches were washed by distilled water to remove soil and other pollutants, then washed with $85 \%$ ethyl alcohol solution and treated with distilled water to prevent infection of adults. Samples were kept for $120 \mathrm{~h}$ in the insectarium to acclimate to the environment and to avoid naturally infected specimens.

\section{Survey of natural Orosanga japonica infections with Beauveria bassiana}

In August and September 2018, wild O. japonica populations on host plants were surveyed for natural infection rates of B. bassiana. Surveys were performed monthly between August and September with an electric aspirator. The area had been checked monthly before the survey, but no infected samples were found. Counts were made over a period of 5 min by randomly selecting 3 trees (same species) infected and the O. japonica individuals were seen. Specimens were collected with and without visual sign with infection (dead and alive) during 5 min. Death/alive specimen ratio was evaluated as the sum of 3 plant collections. Collected death and alive individuals were placed in separate plastic boxes $(34 \times 22$ $\times 12 \mathrm{~cm}$ ) furnished with screen. Each individual was examined under a stereomicroscope for signs of infection by $B$. bassiana. Alive specimens were washed in a $0.5 \%$ sodium hypochlorite solution with $0.01 \%$ Triton X-100 after kiling with ethly acetate for avoiding any cuticular contamination. Then, they were dissected and rinsed twice with sterilized water then placed onto PDA and incubated at $25 \pm 2{ }^{\circ} \mathrm{C}$ for 2 weeks. The presence of fungal infection was evaluated visually. Infection rates were evaluated on all collected (dead, alive) samples.

\section{Efficacy of Beauveria bassiana against Orosanga japonica in the laboratory}

Laboratory assays were to evaluate the efficacy against $O$. japonica with 3 concentrations of B. bassiana. The conidia ratios for efficacy experiments were arranged at $1 \times 10^{4}, 1 \times 10^{5}, 1 \times 10^{6}$ conidia/ml in the suspensions (Tween 80 solution $(0.1 \% \mathrm{v} / \mathrm{v}))$. The direct effect of $B$. bassiana on nymphs and adults $O$. japonica was evaluated by leaf dipping and direct spray methods for leaves with slight modifications (Inanli et al. 2012 and Guven et al. 2015).

\section{Leaf dipping bioassay}

Field blackberry branches with leaves were collected and used. Collected $10 \mathrm{~cm}$ branches with leaves (4-5) were selected. Branches were dipped in the conidia suspension (Tween 80 solution $(0.1 \% \mathrm{v} / \mathrm{v})$ ) for $5 \mathrm{~s}$ and then kept at room temperature for 15-20 min for drying. A piece of cotton, moistened in $5 \mathrm{ml}$ distilled water, was placed on the bottom of the glass jar. Branches with leaves were placed on top of the cotton to prevent drying. Then, 20 acclimatized individuals (nymphs and adults separately) were placed in the glass jars for testing. Tween 80 solution $(0.1 \% \mathrm{v} / \mathrm{v})$ was used as a control with the same procedure.

\section{Direct spray bioassay}

First, cotton moistened with $5 \mathrm{ml}$ distilled water was placed on the bottom of the sterilized glass jar. Leaves were placed with the branches on top of the cotton to prevent drying. Then, 20 acclimatized individuals (nymphs and adults separately) were placed in the glass jars for testing. Sprays were performed with $1 \mathrm{ml}$ of conidia suspension at a time in the glass jar (each concentration included the same amount of conidia) with hand sprayer. Sprayers washed with 1/10 diluted chromic acid and sterilized with 95\% ethyl alcohol between tests. Tween 80 solution $(0.1 \% \mathrm{v} / \mathrm{v})$ was used as a control with the same procedure. The system was maintained at $25 \pm$ $2^{\circ} \mathrm{C}$, with a 12:12 light:dark cycle, over 9 days. Dead specimens were determined 3 times over those 9 days. Whole specimens were washed by sterilized water, placed onto potato dextrose agar (PDA) plates and incubated for 2 weeks at $25 \pm 2{ }^{\circ} \mathrm{C}$ in the dark. Colonies were determined microscopically. The presence of fungal infection was evaluated visually. Infection rates were evaluated on all (dead, alive) samples after testing.

\section{Data analysis}

Mortality rates were evaluated via Probit analysis $\left(\mathrm{LT}_{50}\right)$. Differences between groups were analyzed via one-way ANOVA, and Tukey's test was applied for the evaluation between doses with $p<0.05$ significance level, using the $\mathrm{IBM}^{\circ} \mathrm{SPSS}^{\circ}$ statistics program version 22.

\section{Results and discussion}

Two different fungal isolates were visually determined according to Humber (1997) as B. bassiana. The ITS4-5 region amplicons showed similar agarose gel electrophoresis images (Fig. 1). Sequence results were almost similar for 12 B. bassiana isolates. Amplicons produced 2 haplotypes $(h=2)$, which included one polymorphic site; nucleotide diversity was $\pi=0.5333$. Isolates gene sequences submitted to Genbank with MT350119 (RTEU1), MT350134 (RTEU2) Genbank accession number. The resulting tree had 2 distinct clades. Clade I encompassed JN038191.1 Metarhizium flavoviridae and MF967431.1 M. marquandii GenBank samples. The 2 haplotypes were rooted by MK229193.1, MG345084.1 B. 


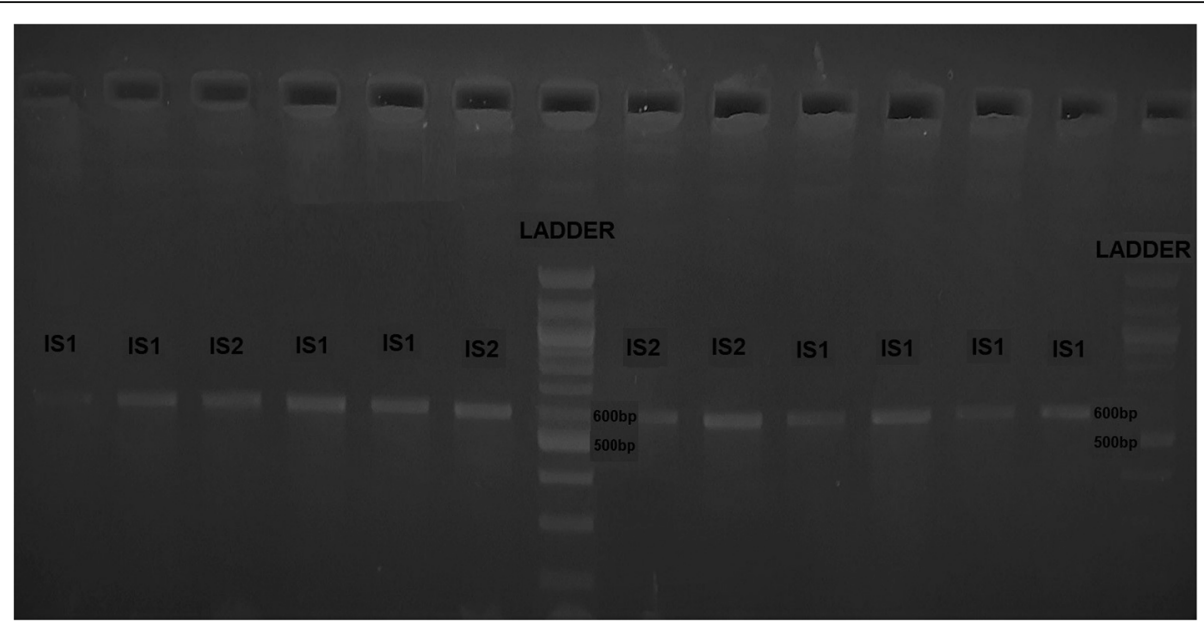

Fig. 1 ITS4-5 amplicon gel electrophoresis results; IS1: isolate 1, IS2 isolate 2, 1, 5\% gel electrophoresis, 45 min run with 60 V. 100-bp ladder was used for identification of the exact amount of amplicons

bassiana samples as a different branch in Clade II. Clade II also encompassed other GenBank fungal samples (Lecanicillium muscarium EF512971.1, L. lecanii EF513006.1, Paecilomyces reniformis DQ069283.1, Isaria farinose KC510278.1, Aspergillus flavus KJ619997.1, Beauveria pseudobassiana KY352711.1) in Clade II (Fig. 2). Isolation and identification of the local pathogens are essential to possible manage pest species in an ecologically sustainable manner. Ribosomal RNA genes are conserved to different degrees and highly divergent spacer area. Internal transcribed spacer (ITS) sequence results have been widely used in fungal separation (Driver et al. 2000 and Cai et al. 2013). The two haplotypes were identified by one polymorphic site. Rehner and Buckley (2005) reported that the two unrelated and morphologically indistinguishable clades from different $B$. bassiana isolates by using ITS1-5.8-ITS2 and EF-1a sequences. Sevim (2010) reported the $23.3 \%$ B. bassiana presence, which isolated from different soil resources in Eastern Black Sea area in Turkey and verified samples by using ITS1-5.8SITS2 region. This study reported that similarity 15 different isolates under one big clade together Rehner ve Buckley (2005) isolates. Ghikas et al. (2010) reported the two main clades for $B$. bassiana strains consisting $B$. bassiana (Clade A) and B. pseudobassiana (Clade C). NJ algorithm revealed that the isolates situated Clade $\mathrm{A}$ and separated B. pseudobassiana (Clade $\mathrm{C}$ ) isolates with high bootstrap value. Although the result revealed the two different haplotypes with ITS region, it needs more detailed study for revealing phylogenetic relation with other isolates and

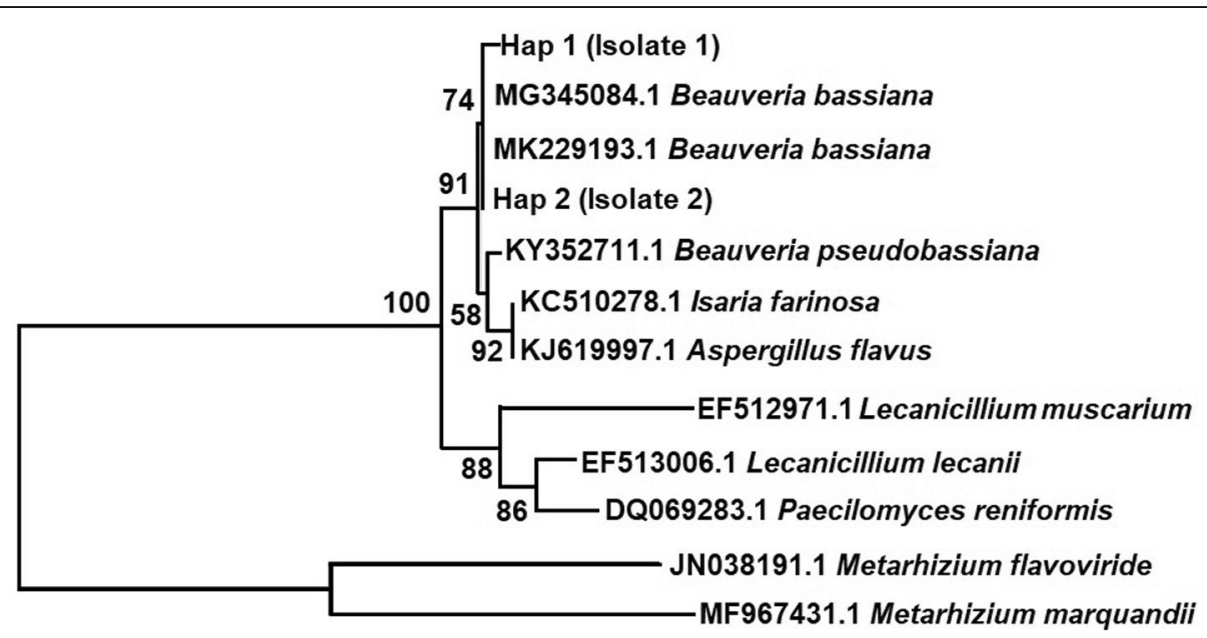

Fig. 2 Phylogenetic relationships between haplotypes of Beauveria bassiana samples in the Eastern Black sea area and other entomopathogenic fungal species. The analysis was based on the neighbor-joining algorithm using the Tamura-Nei genetic distance model, with bootstrap support estimated from 1000 repetitions 
genetic variation by different genetic markers. Even though many authors reported the B. bassiana populations have low genetic diversity (Gaitan et al. 2002), Beauveria isolates showed differences for the virulence (Cruz et al. 2006). Some studies also reported that the genetic homogenity for B. bassiana isolates from a small geographical regions/areas (Muro et al. 2005 and Fernandes et al. 2006). Mar et al. (2012) reported that $99 \%$ similarity between the two $B$. bassiana isolates from different sites and hosts in Northern Thailand. Obtained B. bassiana isolates originating from different points but from the same host. Similarly, the sequences showed a high similarity and one mutational point.

\section{Natural infection of Orosanga japonica with Beauveria bassiana}

The insect species O. japonica is widely distributed in the Eastern Black Sea area and has also been found in the western part of the Black Sea (Demir, 2018 and Arslangundogdu and Hizal 2019). Obtained results also showed that from 2018 to 2019, the population of this species increased. In the 2018 and 2019 active seasons, $O$. japonica adult specimens, naturally infected with $B$. bassiana, were collected from 4 different locations in Rize City (Table 1). Big epizootic situation has not detected yet. Naturally infected specimens are shown in Fig. 3.

In 2018, 2325 specimens were collected during the field study with $5 \mathrm{~min} /$ human collection from 4 different collection points. Mortality rates (NDS\%) ranged between $80.35 \%$ (Findıkl1-August) and 94.8\% (Cayeli-September). Actual infection rates (AIS\%) showed similarity and were higher than mortality rates. Mortality and actual infection rates were higher in September than in August. In August, the mortality rate in Rize City (88.64\%) was higher than in other areas. The lowest

Table 1 Mortality rate and number of specimens infected with Beauveria bassiana over 2018 and 2019

\begin{tabular}{lllllllllllll}
\hline \multicolumn{1}{c}{ August 2018} & \multicolumn{1}{c}{ September 2018} \\
Area & $N$ & NDS & NDS\% & AIS & AIS\% & N & NDS & NDS\% & AIS & AIS\% \\
Alipasa & 302 & 246 & 81.45 & 254 & 84.1 & 225 & 194 & 86.22 & 207 & 92 \\
Rize & 458 & 406 & 88.64 & 411 & 89.73 & 199 & 176 & 88.44 & 189 & 94.97 \\
Cayeli & 382 & 321 & 84.03 & 337 & 88.21 & 250 & 237 & 94.8 & 242 & 96.8 \\
Findikli & 280 & 225 & 80.35 & 262 & 93.57 & 229 & 208 & 90.82 & 211 & 92.13 \\
& August 2019 & & & & September 2019 & & \\
Area & N & NDS & NDS\% & AIS & AIS\% & N & NDS & NDS\% & AIS & AIS\% \\
Alipaşa & 456 & 364 & 79.82 & 371 & 81.35 & 210 & 205 & 97.61 & 208 & 99.04 \\
Rize & 583 & 501 & 85.93 & 519 & 89.02 & 343 & 328 & 95.62 & 341 & 99.41 \\
Çayeli & 489 & 461 & 94.27 & 462 & 94.47 & 412 & 397 & 96.35 & 406 & 98.54 \\
Fındıklı & 386 & 376 & 97.4 & 380 & 98.44 & 356 & 348 & 97.75 & 355 & 99.71
\end{tabular}

Note: $N$ number of specimens collected during 5 min. NDS number of dead specimens, AIS actual infected specimens mortality rate was found in Findıklı (80.35\%). In September 2018, the highest mortality rate was found in Çayeli (94.8). A correlation between mortality rates and infected specimen number was observed.

In 2019, 3192 specimens were collected. Mortality rates ranged between $79.82 \%$ (Alipasa- August) and 97.75\% (Findıklı-September). In August, Findıklı showed the highest mortality rate $(97.4 \%)$. The lowest mortality rate $(79.82 \%)$ and actual infection rate $(81.35 \%)$ were found in Alipaşa. In September, the highest mortality rate was found for Findiklı (97.75\%), similar to August, with a correlation with the actual infection rate. The lowest mortality rate was found for Rize City (95.62\%) and the lowest actual infection rate for Çayeli (98.54\%). In general, more specimens were collected in August than in September, although the mortality and actual infection rates were higher in September than in August. In 2019, more specimens were collected than in 2018 (Table 1).

B. bassiana occurred in various natural soils and is not related to a certain region (Bing and Xing 2008). This species has been isolated from several insect hosts in nature from different regions, including Turkey (Padmavathi et al. 2003).

\section{Efficacy of $B$. bassiana against $O$. japonica in the laboratory}

The results of the efficacy of the 2 different isolates of $B$. bassiana with the 2 different application methods against $O$. japonica nymphs are presented in Table 2 . For isolate 1 , leaf dipping method $\mathrm{LT}_{50}$ results varied between $6.634\left(1 \times 10^{4}\right)$ and 2.92 days $\left(1 \times 10^{6}\right)$. Actual infection results showed correlation and were slightly higher than the mortality rates. For isolate 2, leaf dipping method $\mathrm{LT}_{50}$ results varied between $7.23\left(1 \times 10^{4}\right)$ and 2.56 days $\left(1 \times 10^{6}\right)$. The most efficient results were found via applying the leaf dipping method at the concentration of $1 \times 10^{6}$ conidia/ml concentration, and the $\mathrm{LT}_{50}$ time decreased to almost 2.56 days for isolate 2 at a $1 \times 10^{6}$ conidia/ml concentration.

The results regarding the efficacy of the two different isolates of $B$. bassiana with two different methods against O. japonica adults are presented in Table 3. Similarity with the nymphs' results and consistency between the 2 isolates were noticed. The most efficient results were found via direct spraying at a concentration of $1 \times 10^{6}$ conidia $/ \mathrm{ml}$, and the $\mathrm{LT}_{50}$ time decreased to almost 3.02 days for isolate 1 at a concentration of $1 \times 10^{6}$ conidia $/ \mathrm{ml}$.

In general, direct spraying mortality showed a higher degree than the leaf dipping method, but without a significant difference $(p>0.05)(F=0.79$, significance $=$ 0.37). The application of isolate 2 resulted in a slightly higher $\mathrm{LT}_{50}$ value than isolate 1 for the same concentration $(p>0.05)(F=0.09$ significance $=0.762)$. Although adult 


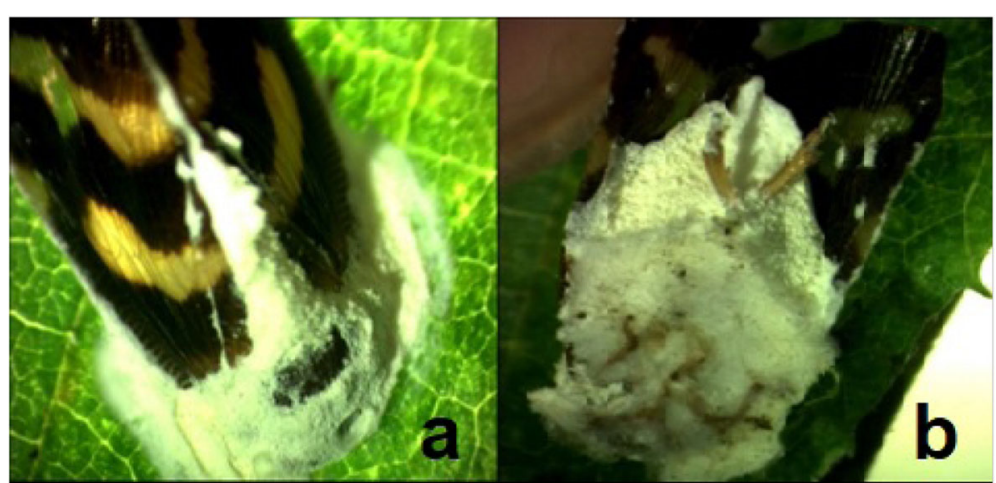

Fig. 3 Adult specimens of Orosanga japonica infected with Beauveria bassiana in the field. a Infected with isolate 2. b Infected with isolate 1

$\mathrm{LT}_{50}$ results were generally higher than those for nymphs, non-significant differences $(p>0.05)(F=0.196$, significance $=0.66$ ) between nymphs and adults were found. The ANOVA results for concentration effects showed significant differences between concentrations $(F=0.196$ significance $=0.000)$. Tukey's test results showed differences $(p<$ $0.05)$ between the first $\left(1 \times 10^{4}\right.$ conidia/ml $)$ and the other two concentrations (significance between 1st and 2nd dose $=0.02$; significance between first $\left(1 \times 10^{4}\right.$ conidia $\left./ \mathrm{ml}\right)$ and third $\left(1 \times 10^{6}\right.$ conidia $\left./ \mathrm{ml}\right)$ concentration $\left.=0.000\right)$. The second $\left(1 \times 10^{5}\right.$ conidia/ml $)$ and third $\left(1 \times 10^{6}\right.$ conidia $\left./ \mathrm{ml}\right)$ concentrations were non-significantly different (significance $=0.08$ ), but close to the $p<0.05$ level.

Three different concentrations against nymphs and adults were tested, of which the concentration of $1 \times 10^{6}$ conidia/ml was the most effective. The highest efficacy of local $B$. bassiana isolates against two life stages of $O$. japonica was reported. The $\mathrm{LT}_{50}$ values decreased with increasing dosage. Numerous studies have investigated the effectiveness of EPF in biological pest control, but studies using O. japonica are limited (Ak et al. 2013 and Gokturk et al. 2018). Guclu et al. (2010) reported that nymphs were more sensitive than adults against the EPF Lecanicillium muscarium, and Lecanicillium muscarium. The $\mathrm{LT}_{50}$ values ranged from 2.34 to 3.90 days, with a single concentration $\left(1 \times 10^{7}\right.$ conidia/ml $)$ against nymphs. Ak et al. (2014) also reported that the Conidiobolus coronatus strain Cc3 had potential in the O. japonica IPM program. $\mathrm{LT}_{50}$ value variation was from 3.19 to 3.66 days with three different $C$. coronatus isolates in a

Table 2 Leaf dipping and direct spraying $L T_{50}$ values against Orosanga japonica nymphs

\begin{tabular}{|c|c|c|c|c|c|c|c|c|c|}
\hline & \multicolumn{5}{|l|}{ Isolate 1} & \multicolumn{4}{|l|}{ Isolate 2} \\
\hline & $\begin{array}{l}\text { Dose } \\
\text { (conidia/ml) }\end{array}$ & $\begin{array}{l}\text { Mortality/actual } \\
\text { infection \% }\end{array}$ & $\mathrm{LT}_{50}$ (days) & $\begin{array}{l}\text { Lower } \\
\text { bound }\end{array}$ & $\begin{array}{l}\text { Upper } \\
\text { bound }\end{array}$ & $\begin{array}{l}\text { Mortality/actual } \\
\text { infection \% }\end{array}$ & $\mathrm{LT}_{50}$ (days) & $\begin{array}{l}\text { Lower } \\
\text { bound }\end{array}$ & $\begin{array}{l}\text { Upper } \\
\text { bound }\end{array}$ \\
\hline \multirow[t]{4}{*}{ Leaf dipping } & $1 \times 10^{4}$ & 74 & 6.634 & $\mathrm{ND}$ & ND & 72 & 7.23 & ND & ND \\
\hline & $1 \times 10^{5}$ & 78 & 4.721 & 4.145 & 5.282 & 79 & 5.68 & ND & ND \\
\hline & $1 \times 10^{6}$ & 89 & 2.922 & 2.159 & 3.505 & 88 & 2.563 & 0.702 & 3.614 \\
\hline & Control & 2 & & ND & ND & 4 & & & \\
\hline \multirow[t]{4}{*}{ Direct spraying } & $1 \times 10^{4}$ & 71 & 5.859 & ND & ND & 70 & 6.958 & ND & ND \\
\hline & $1 \times 10^{5}$ & 90 & 3.947 & ND & ND & 88 & 4.419 & 3.58 & 5.07 \\
\hline & $1 \times 10^{6}$ & 96 & 3.026 & ND & ND & 90 & 2.854 & 1.328 & 3.778 \\
\hline & Control & 3 & & & & 5 & & & \\
\hline \multirow{4}{*}{$\begin{array}{l}\text { Leaf dipping } \\
\text { actual infection }\end{array}$} & $1 \times 10^{4}$ & 76 & & & & 77 & & & \\
\hline & $1 \times 10^{5}$ & 83 & & & & 81 & & & \\
\hline & $1 \times 10^{6}$ & 94 & & & & 95 & & & \\
\hline & Control & 2 & & & & 3 & & & \\
\hline \multirow{4}{*}{$\begin{array}{l}\text { Direct spraying } \\
\text { actual infection }\end{array}$} & $1 \times 10^{4}$ & 80 & & & & 81 & & & \\
\hline & $1 \times 10^{5}$ & 96 & & & & 94 & & & \\
\hline & $1 \times 10^{6}$ & 95 & & & & 93 & & & \\
\hline & Control & 3 & & & & 4 & & & \\
\hline
\end{tabular}


Table 3 Leaf dipping and direct spraying $L T_{50}$ values against Orosanga japonica adults

\begin{tabular}{|c|c|c|c|c|c|c|c|c|c|}
\hline & \multicolumn{5}{|l|}{ Isolate 1} & \multicolumn{4}{|l|}{ Isolate 2} \\
\hline & $\begin{array}{l}\text { Dose } \\
\text { (conidia/ml) }\end{array}$ & $\begin{array}{l}\text { Mortality/actual } \\
\text { infection \% }\end{array}$ & $\mathrm{LT}_{50}$ & $\begin{array}{l}\text { Lower } \\
\text { bound }\end{array}$ & $\begin{array}{l}\text { Upper } \\
\text { bound }\end{array}$ & $\begin{array}{l}\text { Mortality/actual } \\
\text { infection \% }\end{array}$ & $\mathrm{LT}_{50}$ & $\begin{array}{l}\text { Lower } \\
\text { bound }\end{array}$ & $\begin{array}{l}\text { Upper } \\
\text { bound }\end{array}$ \\
\hline \multirow[t]{4}{*}{ Leaf dipping } & $1 \times 10^{4}$ & 67 & 7.416 & ND & ND & 65 & 7.715 & 7.146 & 8.427 \\
\hline & $1 \times 10^{5}$ & 83 & 5.027 & ND & ND & 80 & 5.652 & 5.021 & 6.248 \\
\hline & $1 \times 10^{6}$ & 94 & 3.541 & 3.014 & 3.992 & 89 & 3.675 & 2.585 & 4.426 \\
\hline & Control & 7 & & & & 5 & & & \\
\hline \multirow[t]{4}{*}{ Direct spraying } & $1 \times 10^{4}$ & 71 & 6.618 & ND & ND & 70 & 7.061 & ND & ND \\
\hline & $1 \times 10^{5}$ & 88 & 4.301 & ND & ND & 88 & 4.896 & 4.236 & 5.461 \\
\hline & $1 \times 10^{6}$ & 96 & 3.026 & ND & ND & 93 & 3.153 & 2.002 & 3.917 \\
\hline & Control & 3 & & & & 6 & & & \\
\hline \multirow[t]{4}{*}{ Leaf dipping actual infection } & $1 \times 10^{4}$ & 70 & & & & 72 & & & \\
\hline & $1 \times 10^{5}$ & 90 & & & & 88 & & & \\
\hline & $1 \times 10^{6}$ & 98 & & & & 95 & & & \\
\hline & Control & 3 & & & & 6 & & & \\
\hline \multirow[t]{4}{*}{ Direct spraying actual infection } & $1 \times 10^{4}$ & 79 & & & & 81 & & & \\
\hline & $1 \times 10^{5}$ & 93 & & & & 95 & & & \\
\hline & $1 \times 10^{6}$ & 99 & & & & 94 & & & \\
\hline & Control & 2 & & & & 3 & & & \\
\hline
\end{tabular}

fixed $1 \times 10^{7}$ conidia/ml concentration against nymphs. Obtained results varied from 2.92 to 3.026 days with $B$. bassiana against nymphs and found that the best concentration was $1 \times 10^{6}$ conidia/ml. This variation and concentration efficiency may explain with EPF species and their virulence. Eken et al. (2006) reported that $\mathrm{LT}_{50}$ value variation from 4.6 to 4.4 days with $1 \times 10^{7}$ and $1 \times 10^{8}$ conidia/ml for $B$. bassiana against Saperda populnea. Tuncer et al. (2018) showed that the 4.64 and 8.53 days $\mathrm{LT}_{50}$ value against Curculio nucum adults with one $B$. Bassiana isolate and commercially product in a fixed $1 \times$ $10^{8}$ conidia/ml concentration. Obtained results showed the variations around the $3-8$ days $\mathrm{LT}_{50}$ values testing 3 different concentrations. These results implied that the from $1 \times 10^{6}$ to $1 \times 10^{8}$ concentrations were the best scale for the possible usage of $B$. bassiana isolates as a bio control agent. Göktürk et al. (2018) reported bio-pesticide efficiency against $O$. japonica and found a low efficacy for $B$. bassiana against nymphs and adults (under 20\%). In contrast, obtained results showed a high efficacy against $O$. japonica nymphs and adults with the two natural $B$. bassiana isolates and a high rate of natural infection. These differences may explain preserving conditions after isolation from the field or usage of different test method. Our isolates preserved sub-culturing condition according to the Oliveira et al. (2011) who reported that the subculturing was the best method for B. bassiana preserving. Gokturk et al. (2018) preserved the isolated samples at $86{ }^{\circ} \mathrm{C}$ before the identification and did not give information about the keep condition before and after tests.
Several EPF showed different degrees of efficacy against this pest species, but further detailed studies are necessary to develop environmentally friendly and economically viable biocontrol options. The species $B$. bassiana may be a good control agent for this pest species, but area conditions and toxicity against other arthropods are important when considering commercially usage of it. The Eastern Black Sea area is an important honeybee production area for Turkey and has economically important honey products. There are some reports of the negative effects of $B$. bassiana on the honeybee nest mate recognition ability and longevity (Potrich et al. 2018 and Cappa et al. 2019). The EFSA (European Food Safety Authority) has also released a review of the effects of $B$. bassiana on different animal, soil, and plant species, including the bee brood and nest mate recognition (EFSA, 2015). Against this context, more detailed studies on different isolates, persistence, and toxicological effects on non-target organisms are needed.

\section{Conclusion}

EPFs have become an important component for pest control. B. bassiana is one of the most studied and wellknown EPFs. Obtained results revealed positive potentials against the nymphs and adults of O. japonica under field and laboratory conditions. B. bassiana could be a good component for the area wide insect pest management options for O. japonica but further detailed studies related to the non-target organisms' effects are still needed. 


\section{Abbreviations}

ANOVA: Analysis of variance; ITS: Internal transcribed spacer; h: Haplotype; $\pi$ : Nucleotide diversity; LT50: Lethal time of the $50 \%$ of the population died; NDS: Number of dead specimens; AIS: Actual infected specimens:; N: Number of specimens collected during 5 min; EFSA: European Food Safety Authority; EFP: Entomopathogenic fungus

\section{Acknowledgements}

Not applicable

\section{Authors' contributions}

$\mathrm{MMA}, \mathrm{AU}$, and $\mathrm{MO}$ designed the experiment. MO, IG, and $\mathrm{AU}$ conducted the experiment and wrote the article. MO performed statistical analysis. MMA and $\mathrm{AU}$ revised the article. All authors approved the final article after reading.

\section{Funding}

Not applicable.

\section{Availability of data and materials}

All the data in this study have been presented in this manuscript except laboratory bioassay data for $L T_{50}$. The analyzed data for $L T_{50}$ are available from the corresponding author on reasonable request.

\section{Ethics approval and consent to participate}

Not applicable.

\section{Consent for publication}

Not applicable.

\section{Competing interests}

The authors declare that they have no competing interests.

\section{Author details}

${ }^{1}$ Faculty of Arts and Sciences Department of Biology Rize Turkey, Recep Tayyip Erdoğan University, Rize, Turkey. ${ }^{2}$ Faculty of Arts and Sciences Department of Chemistry, Recep Tayyip Erdoğan University, Rize, Turkey.

\section{Received: 26 March 2020 Accepted: 21 May 2020}

Published online: 02 June 2020

\section{References}

Ak K, Eken C, Guclu S, Genc T, Sekban R (2014) Laboratory and Field Evaluation of the Entomopathogenic Fungus, Conidiobolus coronatus for Controlling Ricania simulans (Walker) (Recaniidae: Hemiptera). Egypt J Biol Pest Control 24(2):455-459

Ak K, Güçlü Ş, Sekban R (2013) A new pest in East Black Sea Region, Ricania simulans (Walker, 1851) determining effectiveness of bio-pesticides with active substances of azadirachtin and spinosad against (Hemiptera: Ricaniidae). J Agric Sci Res 6(1):10-14

Arslangündoğdu Z, Hizal E (2019) New distribution area and host plants for invasive alien insect species, Orosanga japonica (Melichar) in Turkey (Hemiptera: Ricaniidae). Entomol Americana 124(1-4):26-30. https://doi.org/ https://doi.org/10.1664/1947-5136-124.1.26

Bing DS, Xing ZL (2008) Occurrence and diversity of insect-associated fungi in natural soils in China. App Soil Ecol 39:100-108. https://doi.org/https://doi. org/10.1016/.japsoil.2007.12.001.

Cai Y, Pu S, Nie Y, Rehner SA, Huang B (2013) Discrimination of Chinese Beauveria strains by DGGE genotyping and taxonomic identification by sequence analysis of the Bloc nuclear intergenic region. Appl Entomol Zool 48:255-263 http://doi.org/. https://doi.org/10.1007/s13355-013-0179-1

Cappa F, Petrocelli I, Dani FR, Dapporto L, Giovannini M, Silva-Castellari J, Turillazzi S, Cervo R (2019) Natural biocide disrupts nestmate recognition in honeybees. Sci Rep 9(1):1-10. https://doi.org/https://doi.org/10.1038/s41598019-38963-3.

Cruz LP, Gaitan AL, Gongora CE (2006) Exploiting the genetic diversity of Beauveria bassiana for improving the biological control of the coffee berry borer through the use of strain mixtures. Appl Microbiol Biotechnol (2006) 71: 918-926 https://doi.org/https://doi.org/10.1007/s00253-005-0218-0.

Demir E (2009) Ricania Germar, 1818 species of Western Palaearctic Region (Hemiptera: Fulgoromorpha: Ricaniidae). Munis Entomol Zool 4(1):271-275
Demir E (2018) The economically important alien invasive planthoppers in Turkey (Hemiptera: Fulgoromorpha). Acta Entomol Sloven 26(2):231-240

Dinesh DS, Kumari S, Pandit V, Kumar J, Kumari N, Kumar P, Hassan F, Kumar V, Das P, (2015) Insecticidal effect of plant extracts on Phlebotomus argentipes (Diptera: Psychodidae) in Bihar, India. Indian J Med Res 142:95-100. https:// doi.org/https://doi.org/10.4103/0971-5916.176633.

Driver F, Milner RJ, Trueman JWH (2000) A taxonomic revision of Metarhizium based on a phylogenetic analysis of rDNA sequence data. Mycol Res 104 $143-150$

EFSA (2015) Peer review of the pesticide risk assessment of the active substance Beauveria bassiana strain NPP111B005. EFSA J 13(10):42-64

Eken C, Tozlu G, Dane E, Çoruh S, Demirci E (2006) Pathogenicity of Beauveria bassiana (Deuteromycotina: Hypomycetes) to larvae of the small poplar longhorn beetle, Saperda populnea (Coleoptera: Cerambycidae). Mycopathologia 162(1):69-71. https://doi.org/https://doi.org/10.1007/s1 1046006-0035-8.

Fernandes EKK, Costa GL, Moraes AML, Zahner V, Bittencourt VREP (2006) Study on morphology, pathogenicity, and genetic variability of Beauveria bassiana isolates obtained from Boophilus microplus tick. Parasitol Res 98:324-332

Gaitan A, Valderrama AM, Saldarriaga G, Velez P, Bustillo A (2002) Genetic variability of Beauveria bassiana associated to the coffee berry borer Hypothenemus hampei and other insects. Mycol Res 106:1307-1314

Ghikas DV, Kouvelis VN, Typas MA (2010) Phylogenetic and biogeographic implications inferred by mitochondrial intergenic region analyses and ITS1-5. 8S-ITS2 of the entomopathogenic fungi Beauveria bassiana and B. Brongniartii. BMC Microbiol 10:174 https://doi.org/https://doi.org/10.1186/ 1471-2180-10-174.

Gokturk T, Aksu Y (2014) Morphology, biology and damage of Ricania simulans (Walker, 1851) (Hemiptera: Ricaniidae), which harms agricultural and forest areas. Turkey II. Forest Entomol and Pathol Symp (7-9 April 2014), Antalya 279-281. (Turkish).

Gokturk T, Tozlu E, Kotan R (2018) Prospects of Entomopathogenic Bacteria and Fungi for Biological Control of Ricania simulans (Walker 1851) (Hemiptera: Ricaniidae). Pakistan J Zool 50(1):75-82. https://doi.org/https://doi.org/10. 17582/journal.pjz/2018.50.1.75.82.

Guclu S, Ak K, Eken C, Akyol H, Sekban R, Beytut B, YIldırım R (2010) Pathogenicity of Lecanicillium muscarium against Ricania simulans. Bull Insectol 63(2):243246. https://hdl.handle.net/20.500.12427/673.

Guven O, Çayır D, Baydar R, Karaca I (2015). Entomopatojen fungus Beauveria bassiana (Bals.) Vull. izolatlarının patates böceği [Leptinotarsa decemlineata Say. (Coleoptera: Chrysomelidae)] üzerindeki etkisi Turkish J Biol Control 6(2): 107-116. https://dergipark.org.tr/en/pub/tbmd/issue/22435/240082.

Hall TA (1999) BioEdit: a user-friendly biological sequence alignment editor andanalysis program for Windows 95/98/NT. Nucl Acids Symp Ser 41:95-98

Humber RA (1997) Entomopathogenic Fungal Identification. In: Manual of Techniques in Insect Pathology, Lacey, L., A. (Ed.), San Diego, 153-185.

Inanlı C, Yoldaş Z, Birgucu AK (2012) Entomopatojen Funguslar Beauveria bassiana (Bals.) ve Metarhizium anisopliae (Metsch.)'nin Tuta absoluta (Meyrick) (Lepidoptera: Gelechiidae)'nın Yumurta ve Larva Dönemlerine Etkisi. Ege Univ Zir Fak Derg 49(3):239-242. https://doi.org/https://doi.org/10.20289/ zfdergi.69694.

Kumar S, Stecher G, Tamura K. (2016) MEGA7: Molecular Evolutionary Genetics Analysis Version 7.0 for Bigger Datasets. Mol Biol Evol. 33(7):1870-1874. https://doi.org/https://doi.org/10.1093/molbev/msw054.

Mar TT, Suwannarach N, Lumyong S (2012) Isolation of entomopathogenic fungi from Northern Thailand and their production in cereal grains W J Microbiol Biotechnol 28:3281-3291 https://doi.org/https://doi.org/10.1007/s11274-0121139-6.

Mozaffarian F (2018) An identification key to the species of Auchenorrhyncha of Iranian fauna recorded as pests in orchards and a review on the pest status of the species. Zootaxa 4420(4):475-501. https://doi.org/https://doi.org/10. 11646/zootaxa.4420.4.2.

Muro MA, Elliott S, Moore D, Parker BL, Skinner M, Reid W, El Bouhssini M (2005) Molecular characterization of Beauveria bassiana isolates obtained from overwintering sites of sunn pests (Eurygaster and Aelia species). Mycol Res 109:294-306

Oliveira I, Pereira JA, Bento A, Baptista P (2011) Viability of Beauveria bassiana isolates after storage under several preservation methods. Ann Microbiol 61: 339-344 https://doi.org/https://doi.org/10.1007/s13213-010-0147-8

Ownley BH, Griffin MR, Klingeman WE, Gwinn KD, Moulton JK, Pereira RM (2008) Beauveria bassiana: endophytic colonization and plant disease control. J 
Inverteb Path 98(3): 267-270. https://doi.org/https://doi.org/10.1016/j.jp.2008. 01.010

Padmavathi J, Devi KU, Rao CUM. (2003) The optimum and tolerance pH range is correlated to colonial morphology in isolates of the entomopathogenic fungus Beauveria bassiana - a potential biopesticide. W J Microbiol Biot 19: 469-477. https://doi.org/https://doi.org/10.1023/A:1025151000398.

Potrich M, Da Silva RT, Maia FM, Lozano ER, Rossi RM, Colombo FC, Flavia GT, De Gouvea A (2018) Effect of entomopathogens on africanized Apis mellifera L. (Hymenoptera: Apidae). Rev Brasil de Entomol 62(1):23-28. https://doi.org/ https://doi.org/10.1016/j.rbe.2017.12.002.

Rehner SA, Buckley EP (2005) A Beauveria phylogeny inferred from nuclear ITS and EF1-a sequences: evidence for cryptic diversification and links to Cordyceps teleomorphs. Mycologia 97:84-98

Roy HE, Steinkraus DC, Eilenberg J, Hajek AE, Pell JK (2006) Bizarre interactions and endgames: entomopathogenic fungi and their arthropod hosts. Ann Rev of Entomol 51(1): 331-357. https://doi.org/https://doi.org/10.1146/annurev. ento.51.110104.150941.

Rozas J, Ferrer-Mata A, Sánchez-DelBarrio JC, Guirao-Rico S, Librado P, RamosOnsins SE, Sánchez-Gracia A (2017) DnaSP 6: DNA Sequence Polymorphism Analysis of Large Data Sets. Mol Biol Evol 34(12):3299-3302. https://doi: https://doi.org/10.1093/molbev/ms×248.

Sevim A (2010). Isolation and Characterization of Entomopathogenic Fungi from The Eastern Black Sea Region and Determination of Their Virulence. PhD thesis, Karadeniz Technical University.

Sevim A, Demir I, Höfte M, Humber RA, Demirbağ Z (2010) Isolation and characterization of entomopathogenic fungi from hazelnut-growing region of Turkey. Biocontrol 55:279-297

Sung GH, Hywel-Jones NL, Sung JM, Luangsa-ard JJ, Shrestha B, Spatafora JW (2007) Phylogenetic classification of Cordyceps and the clavicipitaceous fungi. Stud Mycol 57:5-59. https://doi.org/https://doi.org/10.3114/sim.2007.57.01.

Thompson JD, Higgins DG, Gibson TJ (1994) Clustal W, improving the sensitivityof progressive multiple sequence alignment through sequence weighting posi-tion specific gap penalties and weight matrix choice. Nucleic Acids Research hitchhiking and background selection. Genetics 147:915-925

Tuncer C, Kushiyev R, Liu J, Akça I (2018) Efficacies of Metarhizium anisopliae and Beauvaria bassiana isolates and products against Curculio nucum Anadolu J Agr Sci 33:116-123. https://doi.org/https://doi.org/10.7161/omuanajas.387380

Van Lenteren JC (2012) The state of commercial augmentative biological control: plenty of natural enemies, but a frustrating lack of uptake. Bio Control 57(1): 1-20. https://doi.org/https://doi.org/10.1007/s10526-011-9395-1.

White JF, Bacon CW, Hywel-Jones NL, Spatafora JW (eds) (2003) Clavicipitalean Fungi: Evolutionary Biology, Chemistry, Biocontrol and Cultural Impacts. Marcel Dekker, New York

White TJ, Bruns T, Lee S, Taylor J (1990) Amplification and direct sequencing of fungal ribosomal RNA genes for phylogenetics. In: Innis MA, Gelfand DH, Sninsky JJ, White TJ (eds) PCR protocols: a guide to methods and applications. Academic, San Diego, pp 315-322

Zimmermann G (2007) Review on safety of the entomopathogenic fungi Beauveria bassiana and Beauveria brongniartii. Biocont Sci Technol 17:553596. https://doi.org/https://doi.org/10.1080/09583150701309006.

\section{Publisher's Note}

Springer Nature remains neutral with regard to jurisdictional claims in published maps and institutional affiliations.

\section{Submit your manuscript to a SpringerOpen ${ }^{\circ}$ journal and benefit from:}

- Convenient online submission

- Rigorous peer review

- Open access: articles freely available online

- High visibility within the field

- Retaining the copyright to your article

Submit your next manuscript at $\boldsymbol{\nabla}$ springeropen.com 